
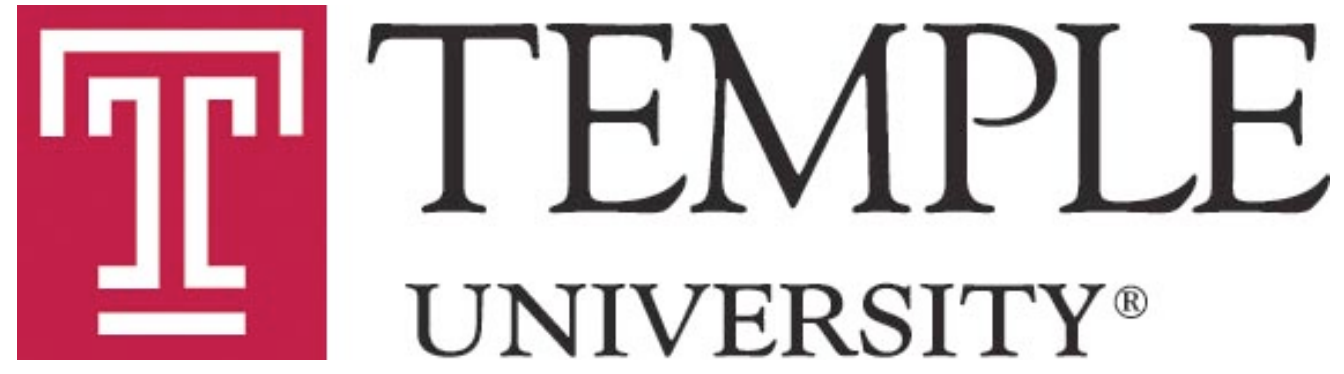

\title{
Promotion Signals, Age and Education
}

by

Michael Bognanno

Eduardo Melero

Department of Economics

DETU Working Paper 12-05

November 2012

1301 Cecil B. Moore Avenue, Philadelphia, PA 19122

http://www.cla.temple.edu/economics/research/working.htm 


\title{
Promotion Signals, Age and Education
}

\author{
Michael Bognanno \\ Temple University \\ IZA - Institute for the Study of Labor \\ Eduardo Melero \\ Universidad Carlos III de Madrid
}

\begin{abstract}
This paper examines whether more informative job promotions carry larger wage increases. In job assignment models with asymmetric information, unexpected promotions send a signal to the external labor market to revise upward their assessment of a worker's ability. The employing firm must then increase wages to prevent the worker from being bid away. Less educated workers are assumed to come from a group with lower average ability. Their promotion is hypothesized to signal a larger positive assessment of their ability than for more highly educated workers for whom promotion is expected. Promotions for younger workers, with less known about their abilities, should also result in strong signaling effects. We find results in accordance with our hypotheses regarding the effect of both age and education on the gains to promotion. However, the statistical significance of the estimates hinges on the promotion definition. Younger workers receive statistically significantly higher wage increases upon promotion only when promotion is defined by the attainment of managerial responsibilities not previously held. Less educated workers obtain statistically significantly larger wage increases upon promotion at a weak level of significance $(10 \%)$ across definitions of promotion but at a high level of significance $(5 \%)$ only when the subjective definition of promotion is used. We interpret the sensitivity to the definition of promotion to suggest that promotions may be heterogeneous in the information they reveal about the employee in way that depends on the characteristics of the employee.
\end{abstract}


Initial studies providing detailed descriptions of the internal labor markets in specific firms helped to stimulate job assignment models with implications consistent with the features of firms documented in these papers. ${ }^{1}$ The features set out included infrequent demotion, large pay increases upon promotion and fast tracks in promotion. Since these job assignment models were designed to explain the existing empirical findings in the literature, testing these theories requires examining implications not already existing in the early empirical literature.

One job assignment model with testable implications beyond those in the initial empirical literature is one that incorporates asymmetric information and a signaling aspect to promotions. Because of the assumption that the employer has private information in regards to worker ability unknown in the external labor market, promotions cause the external labor market to revise upward its estimation of a worker's ability. This induces incumbent employers to behave strategically and makes promotions rarer events (Waldman 1984a). The more unexpected the promotion, the more the worker's ability is revised upward in the external labor market and the stronger earnings must rise for the worker to be retained. The process of testing further implications of asymmetric information in job assignment models and the signaling role of a promotion has begun to some extent with papers by Gibbs (2003), Belzil and Bognanno (2004) and DeVaro and Waldman (2012).

Gibbs (2003) uses the Baker, Gibbs and Holmstrom (1994) data on a single large firm to examine this prediction in two ways. First, he considers the pay change on promotion for employees as a function of the employee's salary percentile within their job title in the preceding year, finding that workers lower in salary receive larger raises upon promotion. Second, he predicts promotion and examines how the wages changes upon promotion vary with the predicted probability of promotion. Consistent with an asymmetric learning model of job assignment, those with a lower predicted probability of promotion received larger pay increase upon promotion.

\footnotetext{
${ }^{1}$ See Baker, Gibbs and Holmstrom (1994, 1994a) and Lazear (1992) for early personnel case studies. Job assignment models designed to be consistent with finding from Baker, Gibbs and Holmstrom include Bernhardt (1995) and Gibbons and Waldman (1999).
} 
Job assignment models have implications for promotion fast tracks originating from two sources. First, more able workers increase in ability faster and achieve the thresholds that trigger promotions more quickly at all hierarchical levels. This source of fast tracks results regardless of informational assumptions. Second, in models of job assignment with asymmetric learning, it is costly for a firm to reveal a signal of high ability to the external labor market because pay must then rise to retain the worker (Waldman, 1984a). For this reason, firms prefer to promote the workers who are already viewed as being of high ability in the external labor market. Since workers with an early initial promotion are viewed as high ability, they have an advantage in subsequent promotion (Bernhardt, 1995). This phenomenon also gives rise to promotion fast tracks. Since revealing strong signals is costly to the firm, less educated workers are less likely to be promoted than equally able workers with more education and, when they are promoted, the level of ability signaled is stronger. Belzil and Bognanno (2004) find some support for the notion that the signaling role of promotion, evidenced through promotion fast tracks, is stronger for less educated workers.

Support for education serving in an informational role in screening for exogenous ability was found in Riley (1979) among others. Assuming years of education is positively correlated with innate ability, labor markets will expect higher ability from educated workers, who will be more likely, all else equal, to achieve promotion. Under asymmetric information, DeVaro and Waldman (2012) derive the implication that the performance level required to achieve promotion is lower for more highly educated workers and that the wage increase associated with promotion is smaller for highly educated workers. They then examine the Baker, Gibbs and Holmstrom data in finding that, controlling for performance, promotion probabilities rise with education, that the education level reduces the wage increase from promotion, except for high school graduates, and last that these results hold more strongly for initial promotions. Two other recent papers empirically examine asymmetric employer learning in which the employer has private information. Pinkston (2009) finds support for the importance of asymmetric employer learning on wages. Schonberg (2007), however, finds learning to be mainly symmetric but with differences between those of differing levels of education. For college graduates, her results might be consistent with asymmetric employer learning. 
This paper follows the approach by DeVaro and Waldman (2012) and looks for evidence of promotion signals by examining pay changes on promotion as a function of age and education. Unlike previous research on the topic, however, we employ data that are representative of a country's population of the full-time workers who maintain a stable employment relationship over the period from 1991 to 2005 . Therefore, our results allow us to evaluate the importance of promotion signals across a national labor market, rather than in the context of a given big firm.

\section{Theory}

The job assignment model is relatively well known in labor economics. We provide simply a sketch to motivate our hypotheses. The model that we present is contained in Gibbons and Waldman (1999) and draws upon several earlier papers. ${ }^{2}$ This paper develops the model with full information and we draw upon Bernhardt (1995) for the case of asymmetric learning.

Identical firms in a competitive market with free entry, producing with only labor, assign workers to three exogenously determined jobs. Output in each job consists of two components, one that is independent of the worker in the job and one that depends on the effective ability of the worker. Effective ability depends on the innate ability of the worker and on labor market experience. The parameters determining output in the three jobs are set to differentially value effective ability such that workers, as they gain experience, progress through the jobs sequentially. Because workers differ in innate ability, they grow in effective ability with labor market experience at different rates and therefore have different speeds of promotion.

The labor market experience of worker $i$ in period $t$ is denoted $x_{i t}$. The worker's innate ability is represented by $\theta_{\mathrm{i}}$ and effective ability by

$$
\eta_{\mathrm{it}}=\theta_{\mathrm{i}} \mathrm{f}\left(\mathrm{x}_{\mathrm{it}}\right)
$$

where $\mathrm{f}^{\prime}>0, \mathrm{f}^{\prime \prime} \leq 0$ and $\mathrm{f}(0)=0$. The output of worker $i$ at time $t$ in job $j(\mathrm{j}=1,2,3)$ is

$$
\mathrm{y}_{\mathrm{ijt}}=\mathrm{d}_{\mathrm{j}}+\mathrm{c}_{\mathrm{j}}\left(\eta_{\mathrm{it}}+\varepsilon_{\mathrm{ijt}}\right)
$$

\footnotetext{
${ }^{2}$ Related papers in the literature include Sattinger (1975), Harris and Holmstrom (1982), Rosen (1982), Waldman (1984a), Waldman (1984b), Bernhardt (1995) and Farber and Gibbons (1996).
} 
where the constants $d_{j}$ and $c_{j}$ are such that $d_{1}>d_{2}>d_{3}>0$ and $0<c_{1}<c_{2}<c_{3}$ and $\varepsilon_{i j t} \sim N\left(0, \sigma^{2}\right)$ is an error term. We define $\eta^{\prime}$ and $\eta^{\prime \prime}$ to indicate the effective abilities at which a worker's expected output is equal between jobs 1 and 2 and jobs 3 and 4 respectively. Hence, $d_{1}+c_{1} \eta^{\prime}=d_{2}+c_{2} \eta^{\prime}$ and $\mathrm{d}_{2}+\mathrm{c}_{2} \eta^{\prime \prime}=\mathrm{d}_{3}+\mathrm{c}_{3} \eta^{\prime \prime}$.

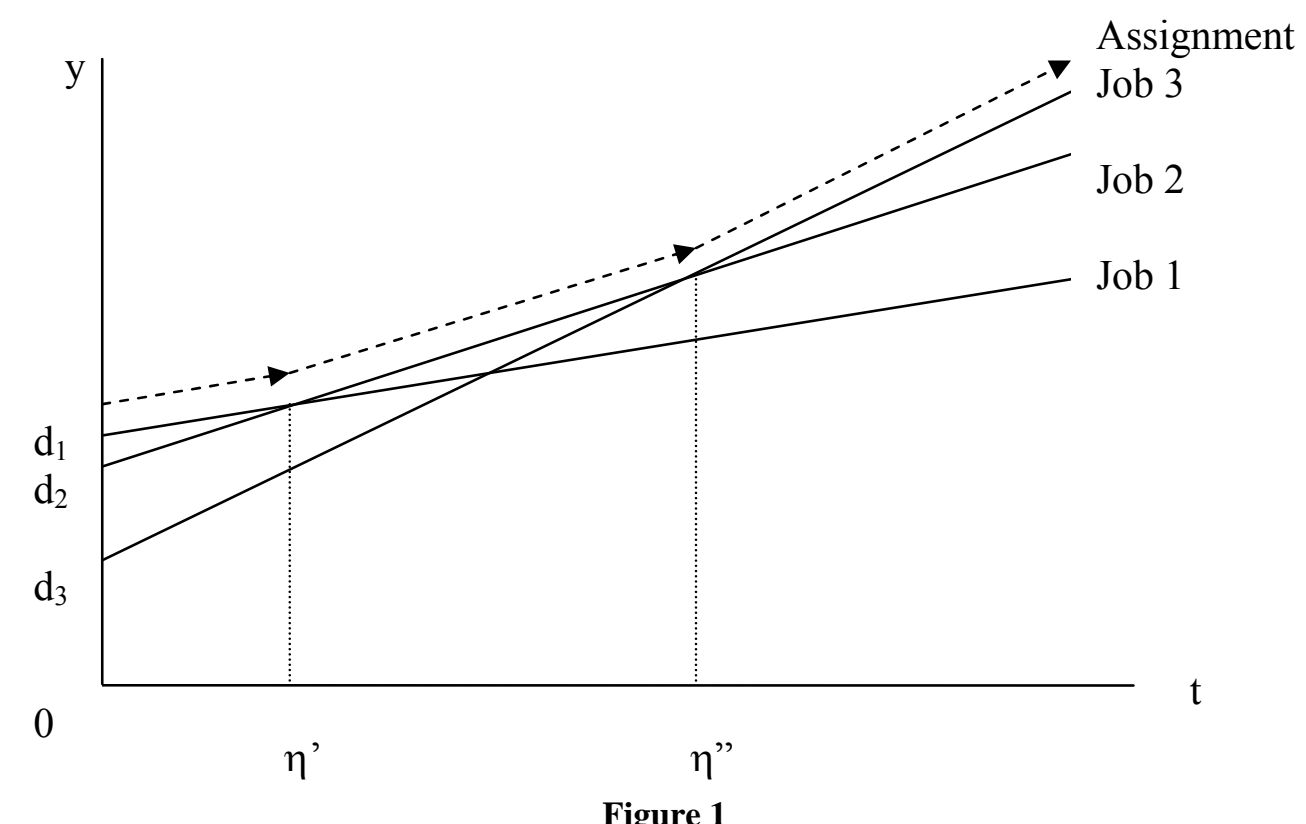

\section{A. Full Information}

In a world of full information ( $\theta_{\mathrm{i}}$ is public knowledge), the assignment of workers maximizes their expected output. Assignment is to job 1 when effective ability, $\eta_{\text {it }}$, is below $\eta^{\prime}$ and to job 2 when $\eta_{\text {it }}$ surpasses $\eta^{\prime}$ but remains below $\eta^{\prime \prime}$ and to job 3 when $\eta_{\text {it }}$ surpasses $\eta^{\prime \prime}$. Entering workers $\left(x_{i t}=0\right)$ are always assigned to job 1 since $f(0)=0$. With full information and competitive markets, wages are set such that $\mathrm{w}_{\mathrm{ijt}}=\mathrm{d}_{\mathrm{j}}+\mathrm{c}_{\mathrm{j}}\left(\eta_{\mathrm{it}}\right)$.

The full information model has implications for both the effect of schooling on promotion, when schooling is a component of $\theta_{\mathrm{i}}$, and fast tracks. The parametric assumption that effective ability, $\eta_{\mathrm{it}}$, is multiplicative in $\theta_{\mathrm{i}}$ and labor market experience, $\mathrm{f}\left(\mathrm{x}_{\mathrm{it}}\right)$, implies that schooling 
increases the growth rate of effective ability and the rate of promotion. ${ }^{3}$ More generally, it implies that workers endowed with higher $\theta_{\mathrm{i}}$ attain the threshold levels of effective ability required for promotion to the next level, $\eta^{\prime}$ and $\eta^{\prime \prime}$, faster than those with less innate ability. In addition to a greater speed of promotion, workers with high innate ability will also have greater wage growth.

Figure 1 illustrates that there is no immediate gain from promotion, just an increase in the marginal return to effective ability. However, with annual observations on earnings and position, workers with greater innate ability $\left(\theta_{\mathrm{i}}\right)$ will gain more from the greater slope parameter $\left(\mathrm{c}_{\mathrm{j}}\right)$ in the new job and have greater wage growth over a given time interval than less able workers who are promoted at the same time. In this sense, higher educated workers should gain more from promotion than less educated workers.

Examining those promoted, information about innate ability may be inferred from the time required to achieve the promotion. Ceteris paribus, workers promoted with the least labor market experience will have the highest innate ability. Their gains from promotion over a given time interval should be larger as they gain effective ability more rapidly and have correspondingly more rapid earnings growth.

\section{B. Asymmetric Learning}

Waldman (1984a) was the first to model outside firms learning about worker ability through the signal provided by job assignment. ${ }^{4}$ Suppose that the current firm is able to perfectly observe worker ability after the initial job assignment but that outside firms can only observe the worker's current and past job assignment, education and wages. In this framework, wages are no longer equal to the expected value of the worker's actual production in the job assigned to maximize output. Instead, wages are associated with the value of the worker as perceived by outside labor market based only on public information. As outside firms infer higher ability to more educated

\footnotetext{
${ }^{3}$ Gibbons and Waldman (2006) add explicit consideration of schooling to the model in a framework of symmetric learning. Worker ability is initially unknown and then gradually revealed through observations of output to all parties. Innate ability, $\theta_{\mathrm{i}}$, is increased by schooling. The interpretation is that schooling increases the speed at which workers learn from experience. More educated workers have a higher ability to learn on the job than less educated workers of equal labor market experience.

${ }^{4}$ Other significant early papers with this information assumption include Ricart i Costa (1988) and Milgrom and Oster (1987).
} 
and rapidly promoted workers, such workers must be paid more by their current firm to avoid being bid away.

In this context of private learning, incumbent employers delay promotions and promote fewer employees that it would be socially efficient. Furthermore, workers from high ability groups will receive more promotions and at a faster pace than equally (or more) able workers from low ability groups. When workers from high ability groups are promoted, the public perception of their ability rises less than when someone from a low ability group is promoted. Since an increase in perceived ability must be met with an increased wage, firms have a bias in favor of promoting those from high ability groups. ${ }^{5}$ Firms are able to exploit high ability workers from low ability groups through underpayment and delayed promotion when their ability has not been signaled to outside firms. Accordingly, promoting educated workers changes the perception of ability less than promoting uneducated workers. Bernhardt (1995) shows that firms will have a bias in favor of promoting educated workers over equally able (or more able) uneducated workers because the wage revision is smaller when promoting those from a more able population. Because the signaling role of promotion is stronger for workers with lower levels of education, those promoted with less education must be exceptionally able.

With promotion, the importance of originating from a high or low ability group becomes less relevant as outside firms draw conclusions based on the employment history. In the context of a model with two job levels, Bernhardt states that once an able worker from a low ability group has been promoted, the worker can no longer be exploited because the worker's ability has been revealed to outside firms. As a worker's employment history and record of promotions lengthens, new learning should diminish. In this regard, the promotion of young workers or workers with little labor market experience should have a greater impact on earnings because the extent of learning by the external labor market should be greater.

Hence, there are two testable implications of promotion signaling in this framework. (1) Just as a top-tier publication adjusts the perception of a new assistant professor more than for an

\footnotetext{
${ }^{5}$ DeVaro and Waldman (2012) find supportive evidence of this implication in that promotion probabilities are greater for those with more education even after controlling for worker performance ratings.
} 
older professor, promotion should be a stronger signal for young workers with little labor market experience, ceteris paribus. This implies that younger workers should experience greater earnings growth on promotion. (2) Less educated workers, expected to be of lower ability on average, should also experience larger earnings growth on promotion than more educated workers, ceteris paribus.

The first hypothesis could result from either the full information model or the asymmetric learning model. With full information, we argued that the promotion of inexperienced workers comes about only when they have high innate ability. Their gains from promotion over a given time interval can be larger just because their earnings growth matches their faster rising effective ability and the higher value placed on it in the higher level job. The second hypothesis, however, is contrary to the implication from the full information model that suggested there should be greater returns to promotion for the more educated with annual observations on earnings, assuming that schooling is correlated with innate ability. If schooling inhibits the wage growth from promotion, it lends support to the job assignment model with asymmetric information and to the notion that education serves as a signal even after a worker's initial position can be observed.

\section{Data}

We test the proposed hypotheses with data from the British Household Panel Survey (BHPS) for the period 1991-2005. The BHPS is an annual panel survey administered by the British Economic and Social Data Service, which interviews each adult member of a nationally representative sample of more than 5,000 households. Among other items, the survey collects job-related information from each interviewed individual, including occupation and employer characteristics. From the total sample of approximately 93,000 observations on roughly 25,000 workers between 16 and 65 years of age, we use a subsample of the full-time, private sector employees with valid data for relevant variables and without employer changes during the year prior to the interview. The result is an unbalanced panel of 20,580 observations from 5,423 individuals.

Promotion can be defined in various ways and is not as simple in practice as it would seem. Our preferred definition is the subjective perception by the worker of having been promoted to a higher level job during last year. To code this variable, we use the job history section of the annual 
survey. Workers are asked about any job changes in the prior year and, if changes occurred, about the type of transition. Thus, we record a subjective promotion between $t-1$ and $t$ when the worker reports in the interview at $t$ that (1) he has stopped doing the job he was doing at $t-1$, that (2) he has started doing a different job for the same employer, and that (3) this job change was a promotion (see the specific questionnaire in Taylor et al., 2010). This definition is the most widely used and has been applied previously in research on the determinants and consequences of job promotions using large-scale worker surveys (Pergamit and Veum, 1999; McCue, 1996; Francesconi, 2001; and Melero, 2010). Since promotions as defined above may involve job changes of varying significance for people in different initial positions, a lack of homogeneity across promotions may exist. To attempt to impose a more stringent standard on what constitutes a promotion, we consider three other possible definitions. One alternative definition is to require an additional condition on the conditions specified above by also requiring a change in the 3-digit 1990 Standard Occupational Classification (SOC) category that each worker declares in their annual interview ${ }^{6}$. A second alternative is not to use the employee's reported transition at all but to focus on the job responsibilities reported by the employee, defining a promotion when the employee obtains specific enhanced decision rights in the firm. The BHPS includes a question on the managerial responsibilities held by the worker that can serve this purpose, so that a worker may be considered to have been promoted to manager whenever managerial responsibilities are reported that were not held in the previous year. Finally, a third alternative is to combine the requirements of a change in SOC category and the assumption of new managerial responsibilities. Requiring newly attained managerial responsibilities offers the advantage of a common threshold, but does not eliminate the risk of coding promotions that vary in magnitude depending on the initial position of the employee.

Table 1 shows the descriptive statistics for the main variables of interest, according to whether employees reported having received a (subjective) promotion last year or not. Promoted workers tend to be younger, more educated and have less job tenure. First and higher-degree university holders, who accumulate 16 to 18 years of education, represent more than $54 \%$ of the sample of promoted employees but less than $42 \%$ of stationary employees. Correspondingly,

\footnotetext{
${ }^{6}$ The BHPS includes information on occupations that distinguishes 374 unit group at the most detailed level. Each unit group is allocated to one of 77 minor groups and one of 9 major groups (see details in Taylor et al., 2010).
} 
workers with no qualification or lowest-level high school certificate (GCE-O), who have 9 to 11 years of education, account for $30 \%$ of promoted employees but almost $44 \%$ of stationary employees. Only for the intermediate category of pre-university graduates (GCE-A), which equates to 13 years of education, is the proportion similar for promoted and stationary workers (around $15 \%$ of the total). Promoted workers are also more likely to hold managerial, professional or technical occupations than stationary ones.

Table 2 describes the proportional average compensation increase following a promotion for workers of each age and education group (in excess of the average compensation increase of stationary workers in the same group). Compensation is measured in real terms (in thousands of 1998 British pounds), and we consider real hourly wages as the compensation outcome ${ }^{7}$. The general pattern that can be extracted from Table 2 is that compensation gains from promotion are smaller for older and more educated groups. However, exceptions are evident. Workers with no education (unfinished school), obtain particularly low wage increases upon promotion in comparison with other groups. Workers under 30 also do not receive the largest pay increases upon promotion in the first four columns. However, the rest of the numbers in the table are largely consistent with the proposition that wage increases upon promotion decrease with age and education. Of course, there are many potential confounding factors that could be at the origin of this pattern and thus regression analysis is needed to formally test our propositions.

\section{Empirical Tests}

To test the two hypotheses, (1) that promotion should be a stronger signal for young workers with little labor market experience, ceteris paribus, and (2) that less educated workers receiving promotions should receive larger earnings increases than more educated workers, ceteris paribus, we specify a regression model as follows:

$$
\begin{aligned}
\ln w_{i j t}-\ln w_{i j t-1}= & \alpha_{1} P_{i j t}+\alpha_{2} * \text { Age }_{i t}+\alpha_{3} P_{i j t} * \text { Age }_{i t}+\alpha_{4} \text { Education }_{i}+\alpha_{5} P_{i j t} * \text { Education }_{i}+X_{i j t} \lambda+\mu_{i}+ \\
& \tau_{j}+\delta_{t}+\varepsilon_{i j t}
\end{aligned}
$$

\footnotetext{
${ }^{7}$ While compensation is most often measured in terms of real hourly wages, a broad concept of ability may include the capacity and predisposition to work long hours. Therefore, an obvious alternative compensation outcome in our analysis would have been real monthly earnings. All the results of this article hold when we consider this second measure of compensation.
} 
where $\ln w_{i j t}$ is the logarithm of compensation of individual $i$ at firm $j$ at time $t . \mathrm{P}_{\mathrm{ijt}}$ is a binary indicator of promotion (any of the four alternatives proposed) between $t-1$ and $t$. For ease of interpretation, Education is measured as the number of years of effective education in excess of the minimum compulsory numbers of years. This variable is based on the information reported by survey respondents about their highest educational qualifications. Analogously, Age is measured in excess of the 16 years of minimum age required to enter the sample. Finally, $X_{i j t}$ is a vector of control variables including individual attributes such as gender and training received last year, firm attributes such as size, industry, region and unionization of the workplace, and job attributes such as occupational category and job tenure. Occupational category is a particularly important control variable. Promotion opportunities and annual changes in productivity and wages may vary across occupations. The occupation of the worker is also likely to be correlated with age and education. Therefore, we include a set of dummy variables capturing the 77 minor-group occupational categories at time $t-1{ }^{8}$ The three terms before the error term, $\varepsilon_{\mathrm{ifj}}$, are factors specific to the individual $\left(\mu_{i}\right)$, firm $\left(\tau_{j}\right)$ or year $\left(\delta_{t}\right)$. Year effects are individually accounted for in the analysis. Individual employee effects are in principle treated as random to improve the efficiency of the estimation and, in order to check robustness, we estimate an individual fixed-effects model. Firm effects are captured with the individual fixed effects and could not be separately conditioned on since these workers do not change employers.

The first prediction from our hypotheses is that $\alpha_{3}$ will be negative, indicating promotion signals are stronger for younger workers. Further, if the pay increase accompanying promotion is larger for less educated workers $\alpha_{5}$ must be negative as well. The promotion-induced gain in earnings should be the strongest for youngest and least educated worker and decrease both with age and years of education. Table 3 shows the results from estimating the proposed model with GLS Random-Effects regression. We present different analyses for the four different definitions of promotion.

Examining the results in regards to education-related promotion signals, we find that the estimation of parameter $\alpha_{5}$ offers support to the signaling theory for our preferred measure of

\footnotetext{
${ }^{8}$ We include minor group dummies in our analysis because it is the most detailed level at which we have a minimum cell size for the estimation of parameters.
} 
promotions. Each additional year of education reduces the real compensation increase upon subjective promotion by $0.54 \%$ of the hourly wage. Given that real compensation increases upon subjective promotion averages $7.1 \%$, the proportional detrimental effect of an additional year of education is around $7.5 \%$ of that value. The estimated effect is consistently negative and relatively large for all the four alternative definitions of promotion. For the definition associated with managerial responsibilities, however, the effect is only significant at the $10 \%$ level.

The results from Table 3 offer weaker support for the hypothesis that wage increases upon promotion decrease with age. Estimates of the coefficient of the interaction of age and promotion, $\alpha_{3}$, are always negative but only statistically significant for two definitions of promotion.

Consistent with the hypothesis, the effect is large and significant for career moves that entail assuming managerial responsibilities. Compensation increases upon this type of promotion, are estimated to decrease between $0.22 \%$ and $0.36 \%$ with each additional year of age, which amount to $3 \%$ to $5 \%$ the size of the average increase upon promotion. On the other hand, estimates of $\alpha_{3}$ are smaller and not statistically significant for definitions of promotion restricted to subjective perception. A possible explanation for this inconsistency in findings is that only the attainment of managerial responsibilities is informative enough to upgrade the belief of a young worker's productivity. If a promotion to management is unusual for a young employee, the accomplishment of such step will have a particularly strong signaling power. Interestingly, the same divergent effects were not observed in regards to years of education.

Though generally supportive of our hypotheses, the combined results from Table 3 suggest that the learning associated with promotion signals does not refer to the one-dimensional concept of ability assumed for the sake of simplicity in theoretical models. Rather, it seems that the market maintains different levels of uncertainty about different types of skills for employees with different characteristics. Since obtaining new managerial responsibilities is associated with large wage increases for young employees but not significantly so for more broadly defined promotions, potential employers may be less uncertain about the general skills and abilities (for instance, accounting or computer skills) of young workers than about their specific ability to manage subordinates. Thus, obtaining a promotion to a position with managerial responsibilities appears to reveal more about this dimension of ability for young workers than the position advancement 
reflected in subjective promotion. On the other hand, the more general definition of promotion does involve a larger wage increases for less educated employees. This suggests that the labor market associates education with the capacity to master the skills necessary for promotions in general, perhaps drawing a correlation between education and learning abilities. Thus, when the less educated receive even a general promotion, a positive signal is revealed to market place about their learning abilities and their wages rise accordingly.

Table 4 provides estimations that address potential sources of unobserved heterogeneity that could affect the results presented in Table 3. One potentially important source is related to the worker's occupation. The minor-group occupation dummies included in the regressions in Table 3 control for differences in occupational wage growth. However, these controls do not account for the possibility that promotions might differ in significance by occupation. If younger or less educated workers tend to hold positions from which promotions are more significant because of larger differences between the new position's requirements and those of the prior position, there could be a bias in the two interaction coefficients associated with our hypotheses testing. Larger pay increases upon promotion would reflect the larger jump in position requirements for younger or less educated workers rather than a signaling effect. This problem is particularly important for the concepts of promotion defined by "the attainment of new managerial responsibilities," since it refers to an objective landmark that entails a new challenge for workers. We address this issue by generating two variables - Education Profile of the Occupation and Age Profile of the Occupation that code the average age and education of the occupation group that each employee reports at $\mathrm{t}-1$ (out of the 374 occupation unit groups). Then, both variables and their interaction with promotion are included in the regression analysis, so that if younger and uneducated worker tend to select into occupations with greater returns to promotion, these effects should be captured.

A second potential omitted factor with a bearing on our results is operation of administrative pay policies that relate to the way in which workers advance through pay grades upon promotion. If a link between age and position tenure exists, it is possible that the higher promotion returns for younger workers results for administrative reasons, not signaling. Workers with greater position tenure will tend to be higher in their pay grade (the base pay range to which a position is assigned) and, consequently, the jump to the next pay grade upon promotion may tend 
to be smaller. This consideration is addressed by introducing an interaction term between job tenure and promotion in the regression analysis.

The first four columns of Table 4 show the estimation results when we control for the above-mentioned variables and interactions. For the two concepts of promotion that involve a subjective assessment (our preferred definitions), the estimated effects are similar to those of Table 3. Even after controlling for the effect of job tenure and the type of initial occupation of the employee (in terms of the average age and education of the workers employed in it), returns to promotion are significantly smaller for more educated workers, while the evidence regarding the effect of age is again inconclusive for subjective promotion. For the concept of promotion that involves new managerial responsibilities, however, the estimated effect of the interaction between education and promotion drops to less than half its value and is not significant with the new controls included. Indeed, the large and significant effect of the Education Profile of the Occupation on returns to promotion suggest that this variable accounts for a substantial part of the estimated effect of employee education presented in the last two columns of Table 3. On the other hand, the significant negative effect of age on the returns to obtaining managerial responsibilities is robust to the introduction of the new control variables in the model.

A third important source of omitted variables concerns employees' unobserved characteristics. There may be worker characteristics related to productivity that are at least partially observable in the labor market but are unobservable to the econometrician. If this source of time-invariant unobserved heterogeneity affects only compensation levels, it should not be problematic for the results in Table 3 that considers wage changes. However, it is possible that more able workers also tend enjoy higher wage increases and, at the same time, are more likely to obtain a promotion ${ }^{9}$. In this case, we would be analyzing differences across age and education in an estimated effect - the wage increase upon promotion - that would be itself biased. To address this concern, we estimate a employee fixed-effects regression model, in which the identification of the promotion interaction terms comes from within-individual differences in annual wage increases according to whether promotion has been achieved or not. The results are presented in the last four

\footnotetext{
${ }^{9}$ Note that the full-information model presented in the theory section assumes that natural ability affects effective ability by increasing the capacity of the worker to learn from experience. This, in turn, generates the prediction that workers with higher natural ability obtain both higher yearly wage increases and higher chances of promotion.
} 
columns of Table 4. Although the estimates are less precise, they follow the same pattern as in the random-effects specifications. They confirm the hypothesis of lower wage increases upon promotion for more educated employees when we consider a subjective definition of promotion. They also support the hypothesis of lower wage increases upon promotion for older workers when we define promotion as the assumption of managerial responsibilities not held before. ${ }^{10}$

\section{Discussion and Conclusion}

This paper presents economy-wide evidence supporting the idea that job promotions serve as signals to the labor market that reveal private employer information regarding worker ability. Employees whose promotions should reveal more information to the market - younger and uneducated workers - get larger pay increases from it. The robustness of these results is sensitive to the definition of promotion used. Once we account for unobserved employee and initial-occupation effects, the impact of education on the returns to promotion is only statistically significant for the concept of promotion that entails the worker's self-reported re-assignment to a higherresponsibility job. In contrast, results regarding the age of workers are only statistically significant when the promotion entails assuming managerial responsibilities. This pattern of findings suggest that, ceteris paribus, employers are particularly uncertain about the management skills of young workers, while they suffer from a more general kind of uncertainty with respect to the ability of uneducated workers.

Our findings with respect to the effect of education on returns to promotion are of particular interest. They suggest that the signaling role of an academic degree has a more complex impact for workers than just on the process of obtaining a first job. It has been argued in the context of job market signaling that obtaining a signal of ability, for instance reaching a specific level of education, may be required for entry into high quality jobs (see Spence 1973). The results here indicate that the effect of the education signal persists beyond the worker's point of entry into the

\footnotetext{
${ }^{10}$ Fixed-effects estimation does not solve the problem of unobserved (to the econometrician) ability being correlated with education levels, since the latter variable is time-invariant. In any case, regarding the ability that is directly observable by the market, more able (and educated) individuals should receive, if anything, greater wage increases upon promotion, not lesser increases (Gibbons and Waldman 1999).
} 
organization. Because pay rises more upon promotion for the less educated, firms have an incentive to (inefficiently) pass over for promotion able but less educated workers. Thus, the detrimental effect of entering the labor market without education may not be restricted to initial pay levels, subsequent advancement may be more difficult in the short term because of asymmetric learning. 


\section{References}

Baker, George, Gibbs, Michael and Holmstrom, Bengt. "The Internal Economics of the Firm: Evidence From Personnel Data," Quarterly Journal of Economics, CIX (1994): 921-955.

. "The Wage Policy of a Firm," Quarterly Journal of Economics, CIX (1994 a): 881-919.

Belzil, Christian and Bognanno, Michael. (2010), "The Promotion Dynamics of American Executives," Research in Labor Economics, Vol. 30 (2010): 189-231.

Bernhardt, Dan. "Strategic Promotion and Compensation," Review of Economic Studies, Vol. 62, No. 2 (1995): 315-339.

DeVaro, Jed and Waldman, Michael. "The Signaling Role of Promotions: Further Theory and Empirical Evidence,” Journal of Labor Economics, Vol. 30, No. 2 (2012): 91-147

Farber, Henry S. and Gibbons, Robert. "Learning and Wage Dynamics," Quarterly Journal of Economics, Vol. 111, No. 4 (1996): 1007-1047.

Francesconi, Marco. "Determinants and Consequences of Promotions in Britain," Oxford Bulletin of Economics and Statistics, Vol. 63, No. 3 (2001): 279-310.

Gibbons, Robert and Waldman, Michael. "A Theory of Wage and Promotion Dynamics Inside Firms," Quarterly Journal of Economics, Vol.114, No. 4 (1999): 1321-1358.

Gibbons, Robert and Waldman, Michael. "Enriching a Theory of Wage and Promotion Dynamics Inside Firms," Journal of Labor Economics, Vol. 24, No. 1 (2006): 59-107.

Gibbs, Michael. "Incentive Compensation in a Corporate Hierarchy," Journal of Accounting and Economics, XIX (1995): 247-277.

Gibbs, Michael. (2003) "Evidence on Wage and Promotion Dynamics in an Internal Labor Market." Mimeo, University of Chicago.

Harris, Milton and Holmstrom, Bengt. "A Theory of Wage Dynamics," Review of Economic Studies, Vol. 49, No. 3 (1982): 315-333.

Lazear, Edward (1992). "The Job as a Concept," in Performance Measurement, Evaluation, and Incentives, ed. William J. Bruns, Jr. (Boston: Harvard Business School Press).

McCue, Kristin. "Promotions and Wage Growth," Journal of Labor Economics, Vol 14 No. 2 (1996): 175-209.

Melero, Eduardo. "Training and Promotion: Allocation of Skills or Incentives," Industrial Relations, Vol. 49, No. 4 (2010): 640-667. 
Pergamit, Michael R., and Jonathan R. Veum. "What Is a Promotion?" Industrial and Labor Relations Review, Vol. 52, No. 4 (1999): 581-601.

Pinkston, Joshua. "A Model of Asymmetric Employer Learning with Testable Implications," Review of Economic Studies, Vol. 76 (2009): 367-394.

Riley, John. "Testing the Educational Screening Hypothesis," Journal of Political Economy, Vol.87, No.5, Part 2 (1979): S227-S252.

Rosen, Sherwin. "Authority, Control, and the Distribution of Earnings," Bell Journal of Economics, Vol. 13, No. 2 (1982): 311-323.

Sattinger, Michael. "Comparative Advantage and the Distributions of Earnings and Abilities," Econometrica, Vol. 43, No. 3 (1975): 455-468.

Schonberg, Uta. "Testing for Asymmetric Employer Learning," Journal of Labor Economics, Vol. 25, No. 4 (2007): 651-691.

Spence, Michael. “Job Market Signaling,” Quarterly Journal of Economics, Vol. 87, No. 3. (1973), pp. 355-374.

Taylor, Marcia Freed (ed.), John Brice, Nick Buck and Elaine Prentice-Lane (2010). "British Household Panel Survey User Manual Volume A: Introduction, Technical Report and Appendices," Colchester: University of Essex.

Waldman, Michael. "Job Assignments, Signaling, and Efficiency," Rand Journal of Economics, Vol. 15, No. 2 (1984a): 255-267.

. "Worker Allocation, Hierarchies and the Wage Distribution," Review of Economic Studies, Vol. 51, No. 1 (1984b): 95-109. 
VII. Tables

Table 1. Data description: Summary statistics

\begin{tabular}{|c|c|c|c|c|c|c|}
\hline Variable & $\begin{array}{l}\text { Mean: } \\
\text { Overall }\end{array}$ & Stationary & Promoted & Std Dev & Min & Max \\
\hline Real Hourly Wage (£1998) & 8.282 & 8.163 & 9.366 & 5.341 & 0.458 & 171.461 \\
\hline Real Monthly Earnings (£1998) & 1402.122 & 1383.147 & 1574.107 & 910.554 & 75.465 & 29719.95 \\
\hline (Subjective ) Promotion & 0.095 & & & 0.293 & 0 & 1 \\
\hline Gender $($ female $=1)$ & 0.327 & 0.323 & 0.362 & 0.469 & 0 & 1 \\
\hline Age & 38.469 & 38.993 & 33.719 & 11.158 & 17 & 65 \\
\hline Job Tenure & 6.809 & 7.392 & 1.526 & 6.347 & 1 & 51 \\
\hline $\begin{array}{l}\text { Received Training (last year) } \\
\text { Education }\end{array}$ & 0.311 & 0.293 & 0.474 & 0.463 & 0 & 1 \\
\hline Total Years of Education & 13.225 & 13.141 & 13.986 & 2.716 & 9 & 18 \\
\hline Unfinished School & 0.128 & 0.136 & 0.053 & 0.333 & 0 & 1 \\
\hline GCE-O or Similar & 0.296 & 0.301 & 0.248 & 0.456 & 0 & 1 \\
\hline GCE-A level & 0.147 & 0.146 & 0.156 & 0.354 & 0 & 1 \\
\hline University First Degree or Similar & 0.408 & 0.397 & 0.512 & 0.491 & 0 & 1 \\
\hline $\begin{array}{l}\text { University: Higher Degree } \\
\text { Initial Occupation }\end{array}$ & 0.021 & 0.020 & 0.032 & 0.143 & 0 & 1 \\
\hline Manager & 0.192 & 0.184 & 0.263 & 0.191 & 0 & 1 \\
\hline Professional and Technical & 0.165 & 0.159 & 0.219 & 0.371 & 0 & 1 \\
\hline Clerical and Craft & 0.346 & 0.351 & 0.304 & 0.476 & 0 & 1 \\
\hline Sales and Services & 0.102 & 0.102 & 0.105 & 0.303 & 0 & 1 \\
\hline Operative and Other & 0.195 & 0.205 & 0.110 & 0.397 & 0 & 1 \\
\hline
\end{tabular}

$\mathrm{N}=20580$ 
Table 2: Data description: Proportional wage increases upon promotion in excess of the average wage increase of stationary workers in the same group.

\begin{tabular}{|c|c|c|c|c|}
\hline $\begin{array}{l}\text { Definition of } \\
\text { Promotion: }\end{array}$ & $\begin{array}{l}\text { Subjective } \\
\text { Promotion }\end{array}$ & $\begin{array}{l}\text { Subjective promotion } \\
\quad+\text { change in SOC }\end{array}$ & $\begin{array}{l}\text { Start assuming } \\
\text { managerial } \\
\text { responsibilities }\end{array}$ & $\begin{array}{c}\text { Start assuming } \\
\text { managerial } \\
\text { responsibilities }+ \\
\text { change in SOC }\end{array}$ \\
\hline Average Increase & 0.0714 & 0.0728 & 0.0318 & 0.0442 \\
\hline \multicolumn{5}{|l|}{ Age Groups } \\
\hline Under 30 & 0.0519 & 0.0532 & 0.0658 & 0.0983 \\
\hline 30-39 Years Old & 0.0815 & 0.0788 & 0.0156 & 0.0036 \\
\hline 40-49 Years Old & 0.0649 & 0.0782 & 0.0173 & 0.0259 \\
\hline 50 or more & 0.0217 & -0.0118 & 0.0009 & 0.0076 \\
\hline \multicolumn{5}{|l|}{ Education Groups } \\
\hline Unfinished School & 0.0437 & 0.0507 & -0.0087 & 0.0131 \\
\hline GCE-O or Similar & 0.0869 & 0.1111 & 0.0468 & 0.0615 \\
\hline GCE-A level & 0.0703 & 0.0632 & 0.0518 & 0.0791 \\
\hline First University & 0.0614 & 0.0524 & 0.0185 & 0.0241 \\
\hline Higher University & 0.0552 & 0.0672 & 0.0470 & 0.0476 \\
\hline Promotion incidence & 0.0948 & 0.0551 & 0.0552 & 0.0329 \\
\hline
\end{tabular}


Table 3: Increase in earnings upon promotion by age and years of education. Log Wage Increase GLS Regressions with Individual Random Effects.

\begin{tabular}{|c|c|c|c|c|}
\hline $\begin{array}{l}\text { Definition of } \\
\text { Promotion: }\end{array}$ & $\begin{array}{l}\text { Subjective } \\
\text { promotion }\end{array}$ & $\begin{array}{c}\text { Subjective } \\
\text { promotion }+ \\
\text { change in } \mathrm{SOC}\end{array}$ & $\begin{array}{l}\text { Start assuming } \\
\text { managerial } \\
\text { responsibilities }\end{array}$ & $\begin{array}{c}\text { Managerial } \\
\text { responsibilities }+ \\
\text { change in SOC }\end{array}$ \\
\hline Variables & $\ln w_{i j t+1}-\ln w_{i j t}$ & $\ln w_{i j t+1}-\ln w_{i j t}$ & $\ln w_{i j t+1}-\ln w_{i j t}$ & $\ln w_{i j t+1}-\ln w_{i j t}$ \\
\hline Promotion & $\begin{array}{c}0.1041^{* * *} \\
(0.0165)\end{array}$ & $\begin{array}{c}0.1225^{* * *} \\
(0.0213)\end{array}$ & $\begin{array}{c}0.0852^{* * *} \\
(0.0233)\end{array}$ & $\begin{array}{c}0.1240^{* * *} \\
(0.0284)\end{array}$ \\
\hline Age & $-0.0020^{* * *}$ & $\begin{array}{c}-0.0021^{* * *} \\
(0.0002)\end{array}$ & $\begin{array}{c}-0.0021^{* * *} \\
(0.0002)\end{array}$ & $-0.0021^{* * *}$ \\
\hline Promotion *Age & $\begin{array}{c}-0.0006 \\
(0.0006)\end{array}$ & $\begin{array}{r}-0.0005 \\
(0.0007)\end{array}$ & $\begin{array}{c}-0.0022^{* * *} \\
(0.0007)\end{array}$ & $\begin{array}{c}-0.0036^{* * *} \\
(0.0009)\end{array}$ \\
\hline Education & $\begin{array}{l}0.0000 \\
(0.0008)\end{array}$ & $\begin{array}{l}0.0000 \\
(0.0008)\end{array}$ & $\begin{array}{r}-0.0001 \\
(0.0008)\end{array}$ & $\begin{array}{c}-0.0002 \\
(0.0008)\end{array}$ \\
\hline Promotion*Education & $\begin{array}{c}-0.0054^{* *} \\
(0.0022)\end{array}$ & $\begin{array}{c}-0.0084^{* * *} \\
(0.0029)\end{array}$ & $\begin{array}{c}-0.0055^{*} \\
(0.0029)\end{array}$ & $\begin{array}{c}-0.0062^{*} \\
(0.0036)\end{array}$ \\
\hline Job Tenure (years) & $\begin{array}{c}-0.0020^{* * *} \\
(0.0007)\end{array}$ & $\begin{array}{c}-0.0022^{* * *} \\
(0.0007)\end{array}$ & $\begin{array}{c}-0.0024^{* * *} \\
(0.0007)\end{array}$ & $\begin{array}{c}-0.0024^{* * *} \\
(0.0007)\end{array}$ \\
\hline Job Tenure sq. $\div 10^{3}$ & $\begin{array}{c}0.0751^{* * *} \\
(0.0273)\end{array}$ & $\begin{array}{c}-0.0801^{* * *} \\
(0.0274)\end{array}$ & $\begin{array}{c}0.0863^{* * *} \\
(0.0274)\end{array}$ & $\begin{array}{c}0.0860^{* * *} \\
(0.0274)\end{array}$ \\
\hline Female & $\begin{array}{c}-0.0075 \\
(0.0049)\end{array}$ & $\begin{array}{c}-0.0077 \\
(0.0049)\end{array}$ & $\begin{array}{c}-0.0080 \\
(0.0049)\end{array}$ & $\begin{array}{c}-0.0081 \\
(0.0049)\end{array}$ \\
\hline Received Training & $\begin{array}{c}0.0082^{* *} \\
(0.0039)\end{array}$ & $\begin{array}{c}0.0089^{* *} \\
(0.0039)\end{array}$ & $\begin{array}{c}0.0110^{* * *} \\
(0.0039)\end{array}$ & $\begin{array}{c}0.0110^{* * *} \\
(0.0039)\end{array}$ \\
\hline Union at Workplace & $\mathrm{-}^{-0.0074^{*}}$ & $\begin{array}{c}-0.0068 \\
(0.0042)\end{array}$ & $\begin{array}{c}-0.0070^{*} \\
(0.0042)\end{array}$ & $\begin{array}{c}-0.0070^{*} \\
(0.0042)\end{array}$ \\
\hline $\begin{array}{l}\text { Constant } \\
\text { Other Controls }\end{array}$ & $\begin{array}{c}0.1182^{*} \\
(0.0714)\end{array}$ & $\begin{array}{l}0.1178 \\
(0.0715)\end{array}$ & $\begin{array}{c}0.3509^{* * *} \\
(0.0717)\end{array}$ & $\begin{array}{c}0.3517^{* * *} \\
(0.0716)\end{array}$ \\
\hline Minor Groups (t-1) & Yes & Yes & Yes & Yes \\
\hline Firm Size Dummies & Yes & Yes & Yes & Yes \\
\hline Industry Dummies & Yes & Yes & Yes & Yes \\
\hline Regional Dummies & Yes & Yes & Yes & Yes \\
\hline Year Dummies & Yes & Yes & Yes & Yes \\
\hline $\begin{array}{r}\mathrm{N} \\
R^{2}\end{array}$ & $\begin{array}{c}20639 \\
0.083\end{array}$ & $\begin{array}{c}20639 \\
0.081\end{array}$ & $\begin{array}{l}20603 \\
0.077\end{array}$ & $\begin{array}{l}20599 \\
0.077\end{array}$ \\
\hline Promotion incidence & 0.0948 & 0.0551 & 0.0562 & 0.0345 \\
\hline
\end{tabular}

Significant at $10 \%$. ${ }^{* *}$ Significant at $5 \% .{ }^{* * *}$ Significant at 1\%. Sample: Full-time, private sectors employees that did not left their employer during last year. 
Table 4: Increase in earnings upon promotion by age and years of education. GLS Random-Effects and Fixed-Effects Log Wage Increase Regressions.

\begin{tabular}{|c|c|c|c|c|c|c|c|c|}
\hline \multirow[b]{2}{*}{ Variables: } & \multicolumn{4}{|c|}{ Random-Effects GLS Regression } & \multicolumn{4}{|c|}{ Fixed-Effects Regression } \\
\hline & $\begin{array}{l}\text { Subjective } \\
\text { promotion }\end{array}$ & $\begin{array}{l}\text { Subjective } \\
\text { promotion }+ \\
\text { change in } \\
\text { SOC }\end{array}$ & $\begin{array}{l}\text { Start assuming } \\
\text { managerial } \\
\text { responsibility }\end{array}$ & $\begin{array}{c}\text { Managerial } \\
\text { responsibility } \\
+ \text { change in } \\
\text { SOC }\end{array}$ & $\begin{array}{l}\text { Subjective } \\
\text { promotion }\end{array}$ & $\begin{array}{l}\text { Subjective } \\
\text { promotion }+ \\
\text { change in } \\
\text { SOC }\end{array}$ & $\begin{array}{l}\text { Start assuming } \\
\text { managerial } \\
\text { responsibility }\end{array}$ & $\begin{array}{c}\text { Managerial } \\
\text { responsibility } \\
+ \text { change in } \\
\text { SOC }\end{array}$ \\
\hline Promotion & $\begin{array}{c}0.0729^{*} \\
(0.0384)\end{array}$ & $\begin{array}{l}0.1026^{* *} \\
(0.0474)\end{array}$ & $\begin{array}{l}0.1943^{* * *} \\
(0.0483)\end{array}$ & $\begin{array}{l}0.2597^{* * *} \\
(0.0610)\end{array}$ & $\begin{array}{c}0.0916^{*} \\
(0.0479)\end{array}$ & $\begin{array}{c}0.1165^{* *} \\
(0.0587)\end{array}$ & $\begin{array}{l}0.1514^{* * *} \\
(0.0479)\end{array}$ & $\begin{array}{l}0.1876^{* *} \\
(0.0743)\end{array}$ \\
\hline Age & $\begin{array}{c}-0.0020 \\
(0.0002)\end{array}$ & $\begin{array}{c}-0.0021^{* * *} \\
(0.0002)\end{array}$ & $\begin{array}{c}-0.0022^{* * *} \\
(0.0002)\end{array}$ & $\begin{array}{c}-0.0022^{* * *} \\
(0.0002)\end{array}$ & $\begin{array}{c}-0.0014 \\
(0.0816)\end{array}$ & $\begin{array}{c}-0.0046 \\
(0.0815)\end{array}$ & $\begin{array}{c}-0.0037 \\
(0.0820)\end{array}$ & $\begin{array}{l}0.0032 \\
(0.0817)\end{array}$ \\
\hline Promotion *Age & $\begin{array}{c}-0.0010 \\
(0.0006)\end{array}$ & $\begin{array}{c}-0.0010 \\
(0.0008)\end{array}$ & $\begin{array}{c}-0.0017^{* *} \\
(0.0008)\end{array}$ & $\begin{array}{c}-0.0030^{* *} \\
(0.0010)\end{array}$ & $\begin{array}{c}-0.0009 \\
(0.0008)\end{array}$ & $\begin{array}{c}-0.0018^{*} \\
(0.0010)\end{array}$ & $\begin{array}{c}-0.0016^{*} \\
(0.0010)\end{array}$ & $\begin{array}{c}-0.0030^{* *} \\
(0.0012)\end{array}$ \\
\hline Education & $\begin{array}{c}-0.0001 \\
(0.0008)\end{array}$ & $\begin{array}{c}-0.0002 \\
(0.0008)\end{array}$ & $\begin{array}{c}-0.0004 \\
(0.0008)\end{array}$ & $\begin{array}{c}-0.0004 \\
(0.0008)\end{array}$ & & & & \\
\hline Promotion*Education & $\begin{array}{c}-0.0054^{* *} \\
(0.0024)\end{array}$ & $\begin{array}{c}-0.0071^{* *} \\
(0.0032)\end{array}$ & $\begin{array}{c}-0.0019 \\
(0.0032)\end{array}$ & $\begin{array}{c}-0.0020 \\
(0.0039)\end{array}$ & $\begin{array}{c}-0.0072^{* *} \\
(0.0028)\end{array}$ & $\begin{array}{c}-0.0101^{* * *} \\
(0.0039)\end{array}$ & $\begin{array}{c}-0.0006 \\
(0.0038)\end{array}$ & $\begin{array}{c}-0.0004 \\
(0.0046)\end{array}$ \\
\hline Job Tenure (years) & $\begin{array}{c}-0.0023^{* * *} \\
(0.0008)\end{array}$ & $\begin{array}{c}-0.0024^{* * *} \\
(0.0007)\end{array}$ & $\begin{array}{c}-0.0024^{* * *} \\
(0.0007)\end{array}$ & $\begin{array}{c}-0.0024^{* * *} \\
(0.0007)\end{array}$ & $\begin{array}{c}-0.0024^{* *} \\
(0.0012)\end{array}$ & $\begin{array}{c}-0.0022^{*} \\
(0.0011)\end{array}$ & $\begin{array}{c}-0.0013 \\
(0.0011)\end{array}$ & $\begin{array}{c}-0.0013 \\
(0.0011)\end{array}$ \\
\hline Promotion*Job Tenure & $\begin{array}{r}0.0027^{*} \\
(0.0017)\end{array}$ & $\begin{array}{c}-0.0040^{*} \\
(0.0022)\end{array}$ & $\begin{array}{c}-0.0002 \\
(0.0016)\end{array}$ & $\begin{array}{l}0.0000 \\
(0.0021)\end{array}$ & $\begin{array}{r}0.0036^{*} \\
(0.0019)\end{array}$ & $\begin{array}{l}0.0063^{* *} \\
(0.0025)\end{array}$ & $\begin{array}{c}-0.0007 \\
(0.0018)\end{array}$ & $\begin{array}{c}-0.0007 \\
(0.0025)\end{array}$ \\
\hline $\begin{array}{l}\text { Age Profile of the } \\
\text { Occupation }\end{array}$ & $\begin{array}{c}0.0017^{*} \\
(0.0010)\end{array}$ & $\begin{array}{r}0.0018^{*} \\
(0.0010)\end{array}$ & $\begin{array}{c}0.0020^{* *} \\
(0.0010)\end{array}$ & $\begin{array}{c}0.0020^{* *} \\
(0.0010)\end{array}$ & $\begin{array}{c}0.0000 \\
(0.0016)\end{array}$ & $\begin{array}{l}0.0000 \\
(0.0016)\end{array}$ & $\begin{array}{l}0.0001 \\
(0.0016)\end{array}$ & $\begin{array}{c}0.0000 \\
(0.0016)\end{array}$ \\
\hline $\begin{array}{l}\text { Promotion*Age of the } \\
\text { Occupation }\end{array}$ & $\begin{array}{c}0.0014 \\
(0.0018)\end{array}$ & $\begin{array}{c}0.0019 \\
(0.0023)\end{array}$ & $\begin{array}{c}-0.0031 \\
(0.00220)\end{array}$ & $\begin{array}{c}-0.0041 \\
(0.0029)\end{array}$ & $\begin{array}{c}0.0008 \\
(0.0022)\end{array}$ & $\begin{array}{c}0.0019 \\
(0.0028)\end{array}$ & $\begin{array}{c}-0.0021 \\
(0.0027)\end{array}$ & $\begin{array}{c}-0.0009 \\
(0.0035)\end{array}$ \\
\hline $\begin{array}{l}\text { Education Profile of } \\
\text { the Occupation }\end{array}$ & $\begin{array}{c}0.0009 \\
(0.0045)\end{array}$ & $\begin{array}{r}0.0012 \\
(0.0045)\end{array}$ & $\begin{array}{l}0.0018 \\
(0.0045)\end{array}$ & $\begin{array}{l}0.0016 \\
(0.0045)\end{array}$ & $\begin{array}{r}-0.0053 \\
(0.0071)\end{array}$ & $\begin{array}{r}-0.0045 \\
(0.0071)\end{array}$ & $\begin{array}{r}-0.0045 \\
(0.0071)\end{array}$ & $\begin{array}{r}-0.0041 \\
(0.0071)\end{array}$ \\
\hline $\begin{array}{l}\text { Promotion* Education } \\
\text { of the Occupation }\end{array}$ & $\begin{array}{r}0.0001 \\
(0.0051)\end{array}$ & $\begin{array}{c}-0.0066 \\
(0.0065)\end{array}$ & $\begin{array}{c}-0.0150^{* *} \\
(0.0064)\end{array}$ & $\begin{array}{c}-0.0190^{* *} \\
(0.0086)\end{array}$ & $\begin{array}{r}0.0007 \\
(0.0062)\end{array}$ & $\begin{array}{r}-0.0037 \\
(0.0078)\end{array}$ & $\begin{array}{r}-0.0130^{*} \\
(0.0077)\end{array}$ & $\begin{array}{c}-0.195^{* *} \\
(0.0010)\end{array}$ \\
\hline
\end{tabular}

${ }^{*}$ Significant at $10 \% .{ }^{* * *}$ Significant at 5\%. ${ }^{* * *}$ Significant at 1\%. Sample: Full-time, private sectors employees that did not left their employer during last year. All the specifications include firm-size, industry, region and year dummies, as well as a set of 77 minor-group occupation dummies. 